OPERATION OF HYDROLOGIC

DATA-COLLECTION STATIONS

BY THE U.S. GEOLOGICAL SURVEY

IN 1997

U.S. Department of the Interior

U.S. Geological Survey

Open-File Report 97-832 


\section{OPERATION OF HYDROLOGIC DATA-COLLECTION}

\section{STATIONS BY THE U. S. GEOLOGICAL SURVEY IN 1997}

Compiled by Melvin Lew

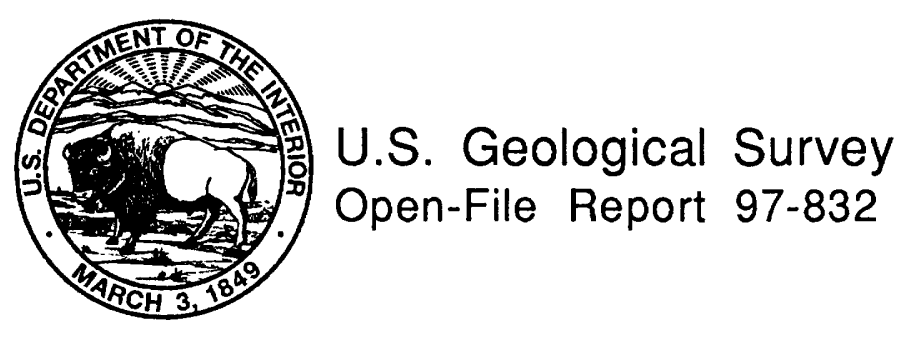

Reston, Virginia

1998 


\section{U.S. DEPARTMENT OF THE INTERIOR \\ BRUCE BABBITT, Secretary}

U.S. GEOLOGICAL SURVEY

Mark Schaefer, Acting Director

For additional information write to:

Assistant Chief Hydrologist for Operations U.S. Geological Survey 441 National Center 12201 Sunrise Valley Drive

Reston, Virginia 20192
Copies of this report can be purchased from:

U.S. Geological Survey

Branch of Information Services

Box 25286

Denver, Colorado 80225-0286 
PAGE

\section{CONTENTS}

ABSTRACT

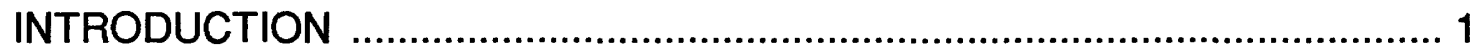

HYDROLOGIC DATA-COLLECTION STATIONS ........................................... 2

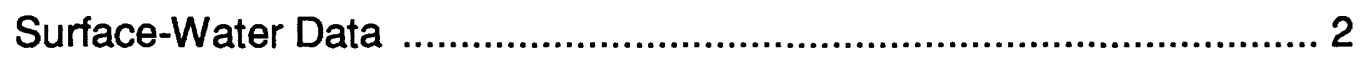

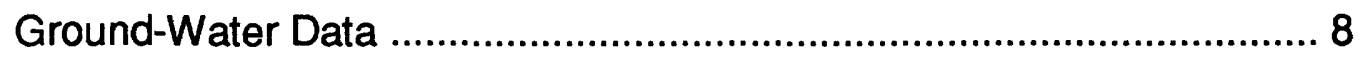

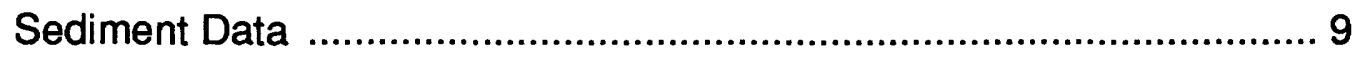

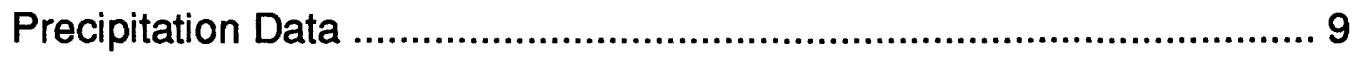

SATELLITE TELEMETRY OF HYDROLOGIC DATA …................................ 9

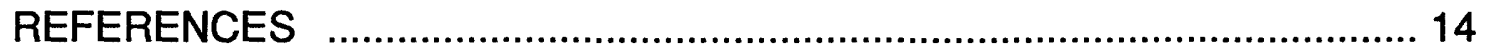

\section{TABLES}

Table 1. Types and number of hydrologic data-collection stations operated by the U. S. Geological Survey from fiscal year 1983 to fiscal year 1997.

Table 2. Types and number of hydrologic data-collection stations operated by the U. S. Geological Survey during the 1997 fiscal year and the sources of funding support

Table 3. Number of continuous surface-water discharge stations, by state and year, from fiscal year 1983 to fiscal year 1997

Table 4. Number of stations, by state, at which surface-water data were collected in fiscal year 1997.

Table 5. Number of stations, by state, at which ground-water data were collected in fiscal year 1997.

Table 6. Number of stations, by state, at which sediment and precipitation data were collected in fiscal year 1997

Table 7. Number of stations, by state, at which data-collection platforms were operated in fiscal year 1997 


\title{
OPERATION OF HYDROLOGIC DATA-COLLECTION STATIONS BY THE U.S. GEOLOGICAL SURVEY IN 1997
}

\author{
Compiled By Melvin Lew
}

\begin{abstract}
The U.S. Geological Survey operates hydrologic data-collection stations nationwide to serve the needs of all levels of government, the private sector, and the general public for water-resources information. During fiscal year 1997, surface-water discharge was determined at 9,317 stations; stage data on streams, reservoirs, and lakes were recorded at 2,043 stations; and various surface-water quality characteristics were determined at 2,299 stations. In addition, ground-water levels were measured at 27,324 sites, and the quality of ground water was determined at 5,534 sites. Data on sediment were collected daily at 142 stations and on a periodic basis at 576 stations. Information on precipitation quantity was collected at 1,480 stations, and the quality of precipitation was analyzed at 50 stations. Data-collection platforms for satellite telemetry of hydrologic information were used at 4,467 U.S. Geological Survey stations. Funding for the hydrologic stations was derived, either solely or in combination, from three major sources--the U.S. Geological Survey's Federal Program appropriation, the Federal-State Cooperative Program, and reimbursements from other Federal agencies.
\end{abstract}

The number of hydrologic stations operated by the U.S. Geological Survey has varied from year to year since fiscal year 1983. Comparing fiscal year 1983 with fiscal year 1997, the number of stations has declined in most categories. The number of continuous-record surface-water discharge stations was lower by 193 . The total number of surface-water discharge stations, both continuous and partial record, was lower by 1,759 . The number of surface-water quality stations was lower by 1,527 . Ground-water level stations were lower by 6,315 , and groundwater quality stations were down by 2,114 .

\section{INTRODUCTION}

The U.S. Geological Survey operates hydrologic data-collection stations throughout the United States, Puerto Rico, and several Trust Territories. These hydrologic data-collection stations are used to monitor the quantity and quality of the water in the Nation's streams, lakes, and reservoirs; changes in ground-water levels; and the quality of ground water.

The purpose of this report is to describe the number, distribution, and source of funding of hydrologic data-collection stations operated during fiscal year (FY) 1997. Similar reports have been prepared previously for fiscal years 1983,1985 , 
1987, 1989, 1991, 1993 and 1995 (Condes de la Torre, 1983, 1985, 1987, 1989, 1991, 1993 and Lew, M., and Dodds, B., 1995). A summary is provided in table 1 of the number of hydrologic stations operated from FY 1983 to FY 1997. The sources of funding support for the stations are the U.S. Geological Survey's Federal Program appropriation, the Federal-State Cooperative Program (Gilbert and Mann, 1993), and reimbursements from other Federal agencies, or a combination of these (table 2).

In 1983, the U.S. Geological Survey established a standard system for counting hydrologic stations so that the type of stations being counted and compared would be consistent from year to year. In 1985, the items to be counted were increased to include stations that are operated to collect daily and periodic sediment sampling data, and information on the number of data-collection platforms (hydrologic data-collection stations equipped with satellite radio transmitters). For this reason, the information presented in this report begins in either 1983 or 1985.

For the purpose of this report, "project" refers to a hydrologic investigation conducted by the U.S. Geological Survey, and a "scheduled, long-term operation" station is one at which measurements are made or samples are taken on a fixed-time interval over an indefinite period. Also, "continuous" and "continuous record" is used interchangeably.

\section{HYDROLOGIC DATA-COLLECTION STATIONS}

\section{Surface-Water Data}

The U.S. Geological Survey determined surface-water discharge (flow) at 9,317 stations in FY 1997 (table 2). At 6,959 of these stations, continuous-discharge records were computed. That is, records were kept such that the flow can be determined for any moment during any day and on a daily basis. These records are needed for forecasting flow extremes, water-management decisions, assessing current water availability, managing water quality, and meeting legal requirements. At 2,358 other streamflow stations, partial records were collected. For example, at a station where the sole interest is in peak flows, data are collected and recorded only at stages greater than some pre-determined level. The design of bridges, dams, water and waste-water treatment facilities are often based on information about flow extremes. The number of stations in each State where continuous surface-water discharge data were collected ranged from 14 in Delaware to 691 in California (table 3). The Federal-State Cooperative Program funded operation of the largest number of continuous surface water discharge stations; it provided sole support for 4,080 stations, and in combination with other sources, provided support for $(77,+375,+43) 495$ more (table 2). The FederalState Cooperative Program also funded the largest number of partial-record discharge stations; it provided sole support of 1,913, and in combination with other sources, funded 33 more stations (table 2). 


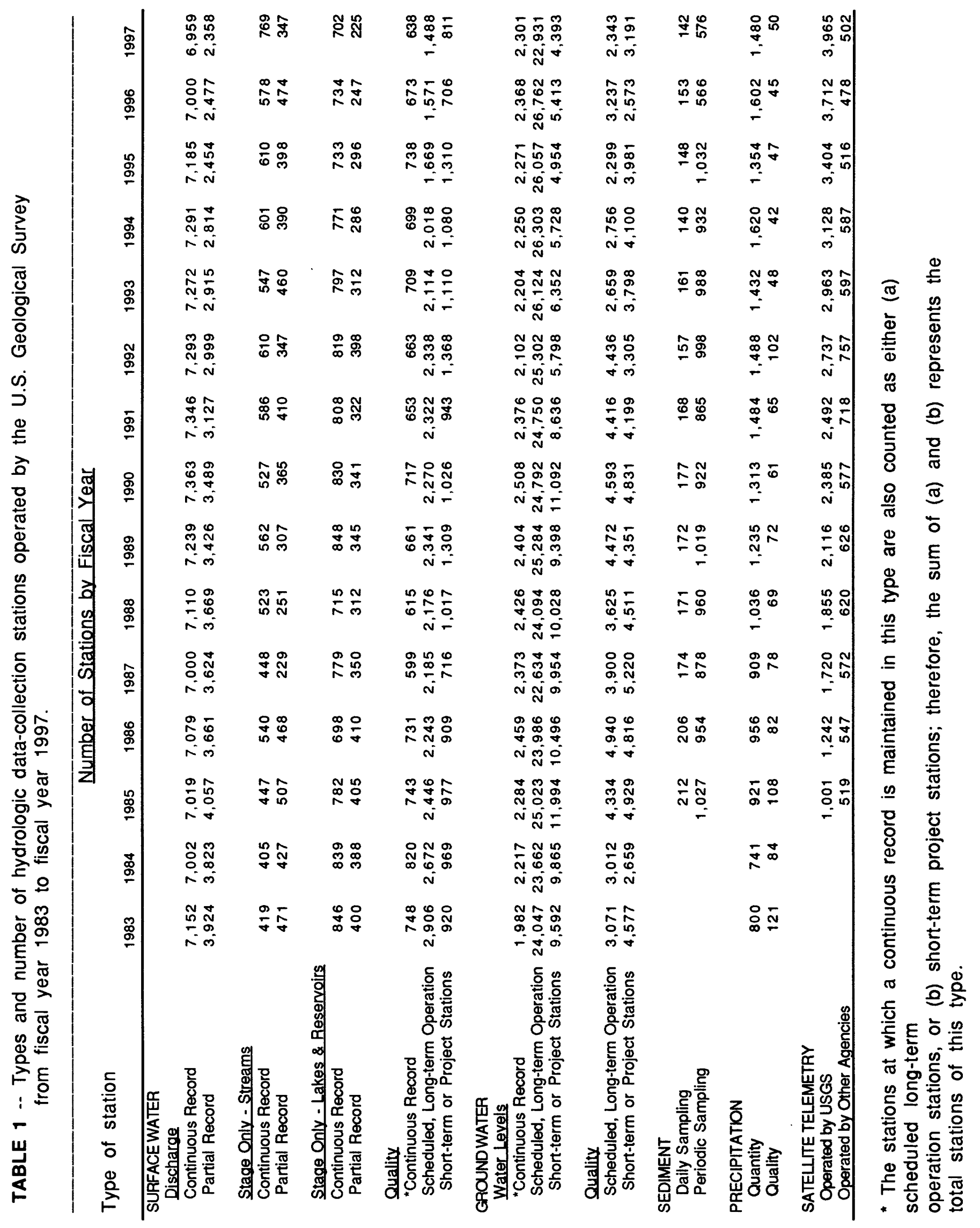




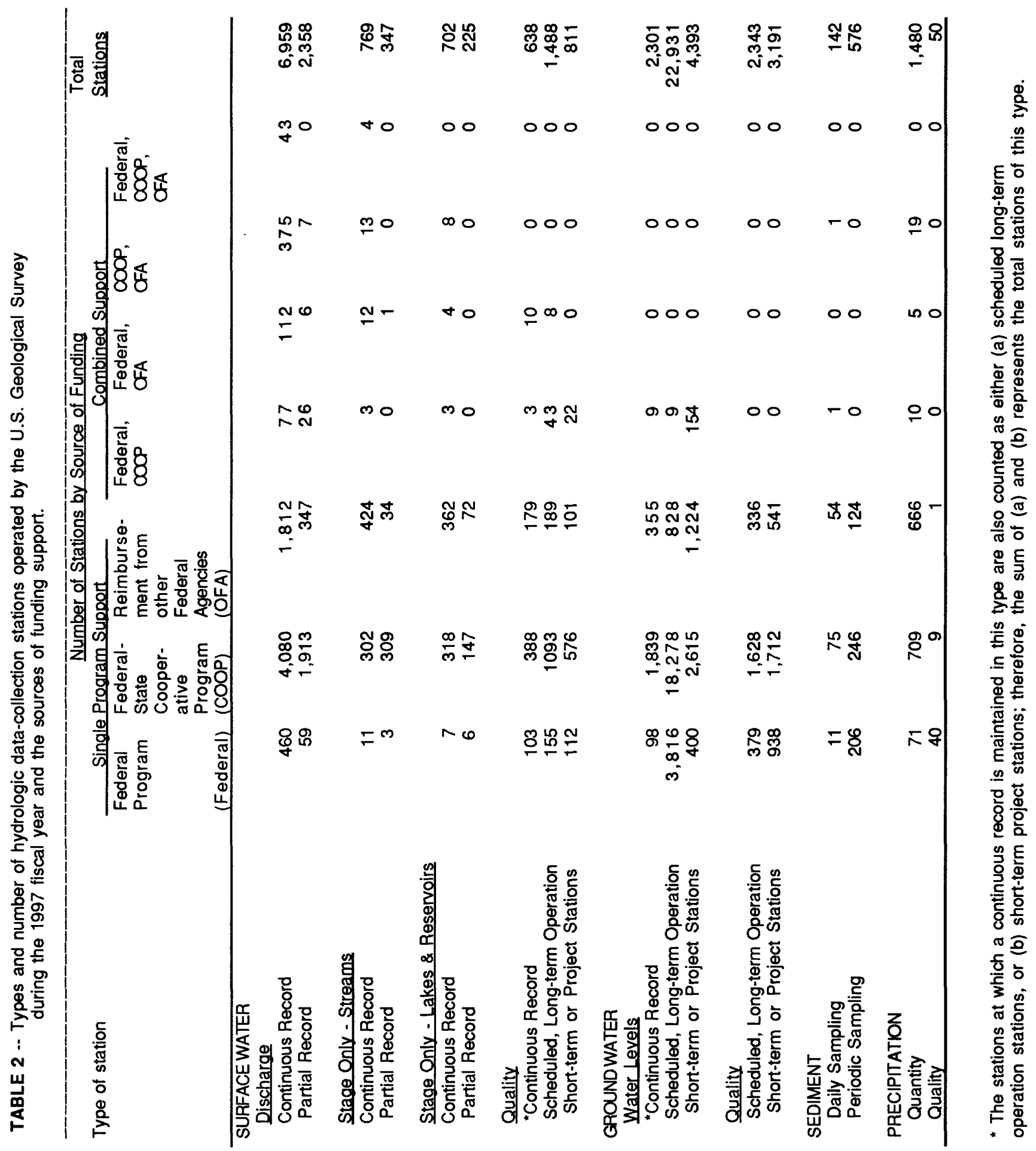


Table 3. -- Number of continuous surface-water discharge stations, by state and year, from fiscal year 1983 to fiscal year 1997

NUMBER OF STATIONS

EISCAL YEAB

STATE

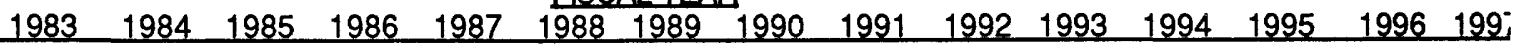

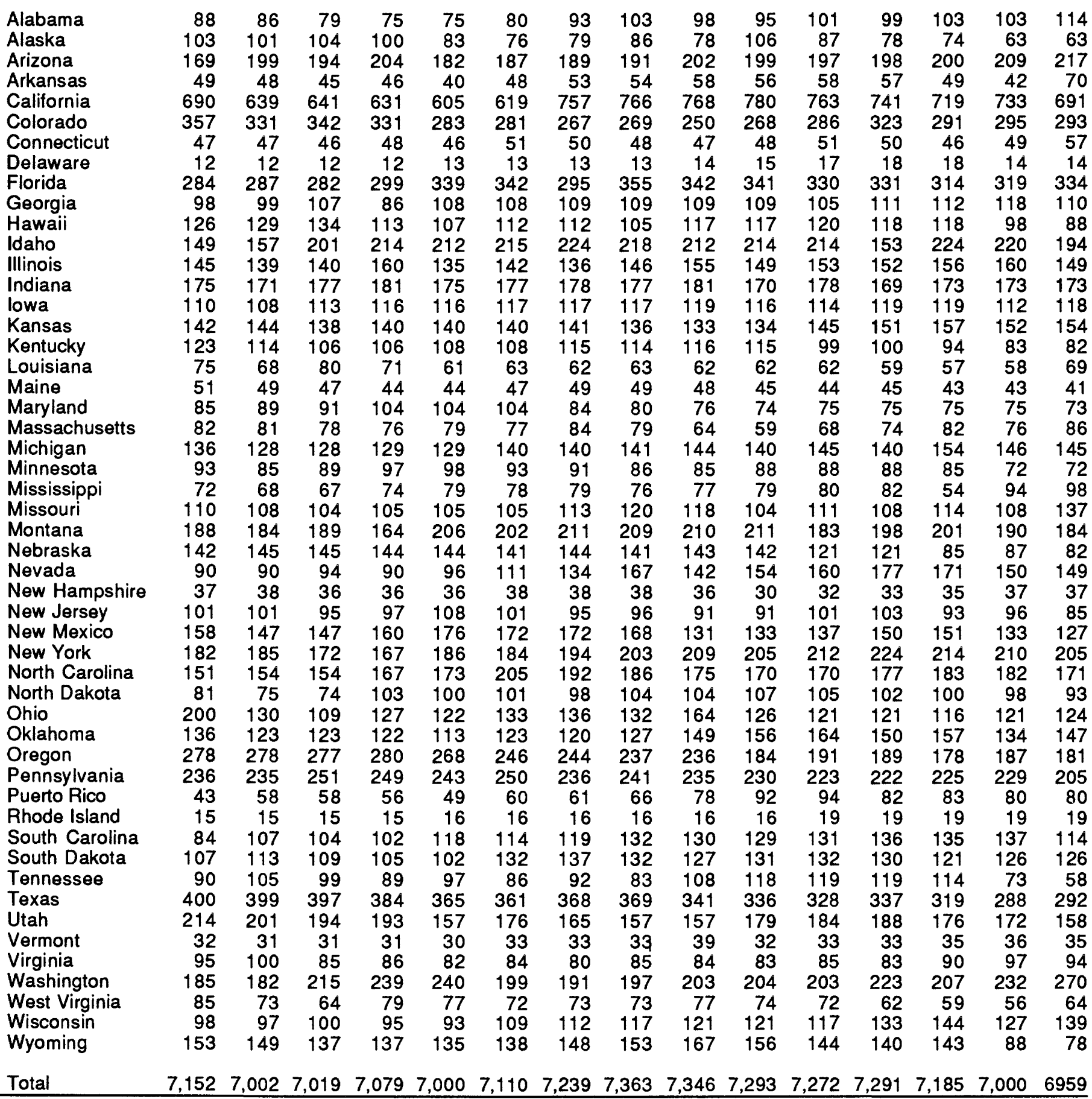


The U.S. Geological Survey's hydrologic data-collection surface water stations used to monitor and document changes and trends in water availability and quality has undergone reductions in recent years. The number of continuousrecord surface-water discharge stations varied from 7,152 stations in FY 1983 to the present low of 6,959 stations (table 1). In FY 1990, U.S. Geological Survey had the highest number of stations at 7,363. Station reductions were not distributed uniformly across the country and were generally those that were funded primarily from direct USGS Federal Program. The changes in the number of stations, since 1983, reflect decreases in some States and increases in others (table 3 ).

Over the past year, the number of partial record surface-water discharge stations decreased by 119, to 2,358 stations in FY 1997.

The U.S. Geological Survey collected stage-only data at 1,116 stream stations. The number of stage-only, continuous and partial, data stations on streams ranged from none in several States to 126 in Washington (table 4). The reimbursement from other Federal agencies supported the largest number of continuous stage-only stream stations--424, while the Federal-State Cooperative Program supported the most partial-record stage-only stations--309 (table 2). The number of continuous-record stations collecting stage-only data on streams increased from 419 in 1983 to a high of 769 in 1997 (table 1), whereas the number of partial-record stations decreased by 124 .

The U.S. Geological Survey also collected stage data at 927 stations on lakes and reservoirs. Continuous records of stage were collected at 702 lake and reservoir stations, ranging from 143 in California to none in several States (table 4). Reimbursements from the Federal-State Cooperative Program and other Federal agencies supported 97 percent of the continuous-record stations and partial-record stage stations on lakes and reservoirs (table 2). The number of stage stations on lakes and reservoirs decreased from 1,246 in FY 1983 to 927 in FY 1997 (table 1).

Water-quality characteristics were measured at 2,299 stations across the Nation (table 1). The types of chemical constituents and physical properties measured vary from site to site. Field and laboratory determinations could include: support variables such as temperature, specific conductance, $\mathrm{pH}$, alkalinity, turbidity and dissolved oxygen; major dissolved cations and anions; dissolved and suspended trace elements; nutrients; and pesticides. A continuous record was maintained at 638 of these sites, mainly for water temperature and conductance, but other properties, such as dissolved oxygen concentrations and $\mathrm{pH}$, were also recorded continuously at some sites. The surface-water quality stations at which a continuous record is maintained are also included in the count of (a) scheduled long-term operation stations, or (b) short-term project stations; therefore, the sum of (a) and (b) represents the total stations of this type. 
Table 4,-Number of stations, by state, at which surface-water data were collected in fiscal year 1997

Iype of Station

State

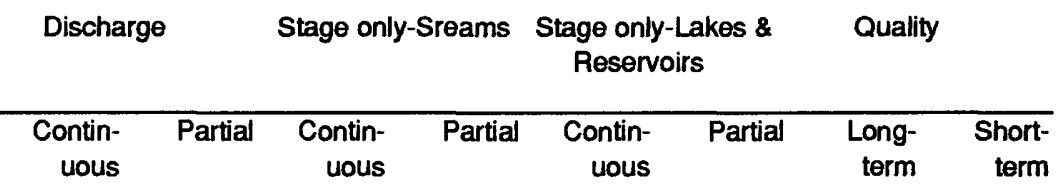

Alabama

Alaska

Arizona

Arkansas

California

Colorado

Connecticut

Delaware

Florida

Georgia

Hawaii

Idaho

Illinois

Indiana

lowa

Kansas

Kentucky

Louisiana

Maine

Maryland

Massachusetts

Michigan

Minnesota

Mississippi

Missouri

Montana

Nebraska

Nevada

New Hampshire

New Jersey

New Mexico

New York

North Carolina

North Dakota

Ohio

Oklahoma

Oregon

Pennsylvania

Puerto Rico

Rhode Island

South Carolina

South Dakota

Tennessee

Texas

Utah

Vermont

Virginia

Washington

West Virginia

Wisconsin

Wyoming

114

63

217

70

691

293

57

14

334

110

88

194

149

173

118

154

82

69

41

73

86

145

72

98

137

184

82

149

37

85

127

205

171

93

124

147

181

205

80

19

114

126

58

292

158

35

94

270

64

139

78

25

40

0
4
0
0

36

124

14

34

0

114

112

10

14

0

92

33

0

45

0

67

22

37

$$
86
$$

$$
58
$$

2
109

44

102

14

85

64

178

68

8

66

$$
\begin{array}{r}
66 \\
0
\end{array}
$$

$$
\begin{array}{r}
8 \\
79
\end{array}
$$

1

21

13

23

97

97
61

61
0

1

$34-16$

2
15

15
13

13

0
5

6

6
22

22

5
6

6
79

23

0$$
\begin{array}{r}
2 \\
15 \\
5
\end{array}
$$$$
5
$$$$
\begin{aligned}
& 4 \\
& 7
\end{aligned}
$$$$
\begin{array}{r}
7 \\
47
\end{array}
$$$$
67 \quad 50
$$

$\begin{array}{rrrr}1 & 0 & 34 & 16 \\ 1 & 1 & 0 & 0 \\ 0 & 0 & 29 & 7\end{array}$

1
132

13

13
0

0

$23 \quad 22$

$25 \quad 46$

$126 \quad 5$

$\begin{array}{rr}126 & 5 \\ 33 & 2\end{array}$

2
0
6

0
29

0

0
95

$48 \quad 0$

$\begin{array}{rr}48 & 114 \\ 1 & 14\end{array}$

$\begin{array}{rr}1 & 14 \\ 57 & 8\end{array}$

26

$\begin{array}{ll}0 & 0 \\ 2 & 0\end{array}$

$3 \quad 38$

$28 \quad 2$

$11 \quad 10$

10

124

130

$21 \quad 26$

$\begin{array}{rr}2 & 45 \\ 34 & 9\end{array}$

$56 \quad 31$

$26 \quad 44$

$13 \quad 23$

$1 \quad 61$

$0 \quad 0$

$87 \quad 51$

$41 \quad 2$

$21 \quad 10$

190

$123 \quad 11$

$0 \quad 17$

$31 \quad 16$

20

$53 \quad 33$

$73 \quad 0$

$\begin{array}{rr}7 & 0 \\ 29 & 3\end{array}$

$28 \quad 3$

64

15630

95

$\begin{array}{rr}7 & 12\end{array}$

$0 \quad 1$

$\begin{array}{rr}4 & 2 \\ 62 & 38\end{array}$

Totals

6959

2358

769

347

702

225

1488

811 
There were 811 stations in FY 1997 that were sampled as short-term or project stations. Water quality data were collected at 1,488 stream sites as part of a scheduled, long-term operation. The collection of surface-water quality data received its largest funding support from the Federal-State Cooperative Program for all types of stations (table 2). The number of stations at which surface-water quality data were collected has been in declined since FY 1992. The number of stations in FY 1992 was 3,706, and in FY 1997 the number of stations had dropped to 2,299 (table1).

\section{Ground-Water Data}

Ground water is one of the most widely available of the Nation's natural resources. It is estimated that 79 billion gallons per day of ground water are withdrawn in the United States for public supply domestic, commercial, irrigation, livestock, industrial, mining, and thermo-electric uses (Solley and others, 1993). Water-level fluctuations are indicators of the stresses (both natural and maninduced) placed on aquifers, their ability to yield water, and the quantity of water in storage beneath the earth's surface. Ground-water investigations are carried out by more than 150 USGS field offices and provides water managers and policymakers with technical information to understand long-term ground-water resource issues. The U.S. Geological Survey collected information on groundwater levels at 27,324 sites in 1997 and water levels were recorded continuously at 2,301 sites (table 1). The stations at which a continuous record of groundwater levels is maintained are also included in the count of (a) scheduled, longterm operation stations, or (b) short-term project stations; therefore, the sum of (a) and (b) represents the total stations of this type. Ground-water levels were measured at 22,931 stations as part of a scheduled, long-term operation to assess long-term trends. When special area studies were conducted, water levels were at times measured at short-term or project stations to supplement the information available in the area from the long-term stations. In FY 1997, waterlevel data were collected at 4,393 stations for these investigations. The FederalState Cooperative Program provided total funding support for 76 percent of the long and short-term or project stations (table 2).

In FY 1997, samples of ground water from 5,534 stations were analyzed to provide information on the changes in water quality. Samples were collected at 2,343 stations as part of a scheduled long-term operation. Of these, the FederalState Cooperative Program provided the total funding support at 1,628 stations. Ground-water quality data were also collected at 3,191 stations to provide information needed for short-term, generally site-specific, studies (table 2).

From FY 1983 to FY 1997, the number of scheduled, long-term operation ground-water level stations have varied from a low of 22,634 in FY 1987 to a high of 26,762 in FY 1996 (table 1). Across the country, the number of stations at 
which ground water data were collected in FY 1997 has varied from state to state (table 5).

\section{Sediment Data}

Data are needed to evaluate the effects of sediment deposition on reservoir storage; the influence of infrequent large storms on erosion and transport of sediment; and the effects of urban and rural non-point contributions of sediment and the associated transport and fate of nutrients, toxic metals, and organic substances. Burkham (1985) states: "The U.S. Geological Survey (USGS) and other Federal, State, and local agencies obtain records of suspended-sediment discharge at many sites throughout the United States. The use of these records has greatly increased in recent years. Uses involve the evaluation of sediment transport to the oceans, geomorphological studies of denudation and rates of erosion, assessment of soil erosion and soil loss, reservoir sedimentation, general environment impact assessment, water treatment problems of sedimentassociated nutrients and pollutants, and evaluation of the precise impacts of humans."

To help address the problems and issues of sediment in rivers, the U.S. Geological Survey collected daily sediment data at 142 stations and periodic data at 576 other stations distributed nationwide in FY 1997 (table 6). From FY 1985 to FY 1997, the number of stations where sediment data was collected has varied from year to year (table 1).

\section{Precipitation Data}

The U.S. Geological Survey collects precipitation data only as part of ongoing investigations of specific hydrologic systems. Precipitation data were collected at 1,480 sites nationwide (table 6). At 50 of these sites, the chemical quality of precipitation was determined. In FY 1997, the Federal-State Cooperative Program and reimbursements from other Federal Agencies were the largest sources of funding support for the collection of precipitation quantity and quality data (table 2). The number of sites at which precipitation data were collected has varied from year to year-from 800 in FY 1983 to 1,480 in FY 1997 (table 1).

\section{SATELLITE TELEMETRY OF HYDROLOGIC DATA}

Satellite telemetry is playing an increasing role in the collection of hydrologic data in real time. A satellite data-collection system consists of a data-collection platform (which, in general, is a small battery-operated radio transmitter), an Earth-orbiting satellite, and an Earth receive and data-processing station. The demand for a cost-effective means of collecting hydrologic data in real time for hazard-warning systems and water management has increased rapidly (Paulson and Shope, 1984). In 1995 the U.S. Geological Survey began to provide real 
Table 5.-- Number of stations, by state, at which ground-water data were collected in fiscal year 1997

\begin{tabular}{|c|c|c|c|c|}
\hline \multirow{3}{*}{ State } & \multicolumn{4}{|c|}{ Type of Station } \\
\hline & \multicolumn{2}{|c|}{ Water Levels } & \multicolumn{2}{|c|}{ Quality } \\
\hline & $\begin{array}{l}\text { Long- } \\
\text { term }\end{array}$ & $\begin{array}{c}\text { Short- } \\
\text { term }\end{array}$ & $\begin{array}{c}\text { Long- } \\
\text { term }\end{array}$ & $\begin{array}{r}\text { Short- } \\
\text { term }\end{array}$ \\
\hline Alabama & 19 & 0 & 0 & 0 \\
\hline Alaska & 60 & 50 & 0 & 0 \\
\hline Arizona & 39 & 700 & 87 & 81 \\
\hline Arkansas & 402 & 32 & 5 & 42 \\
\hline California & 941 & 227 & 219 & 51 \\
\hline Colorado & 670 & 154 & 165 & 150 \\
\hline Connecticut & 72 & 0 & 0 & 2 \\
\hline Delaware & 55 & 35 & 0 & 40 \\
\hline Florida & 1649 & 0 & 192 & 19 \\
\hline Georgia & 2221 & 10 & 118 & 0 \\
\hline Hawaii & 68 & 0 & 92 & 0 \\
\hline Idaho & 690 & 315 & 409 & 146 \\
\hline Illinois & 13 & 0 & 13 & 60 \\
\hline Indiana & 0 & 0 & 0 & 0 \\
\hline lowa & 228 & 0 & 0 & 90 \\
\hline Kansas & 0 & 15 & 0 & 26 \\
\hline Kentucky & 171 & 35 & 0 & 30 \\
\hline Louisiana & 386 & 0 & 194 & 0 \\
\hline Maine & 3 & 13 & 0 & 0 \\
\hline Maryland & 779 & 2 & 4 & 152 \\
\hline Massachusetts & 168 & 6 & 0 & 25 \\
\hline Michigan & 22 & 125 & 0 & 91 \\
\hline Minnesota & 2 & 115 & 0 & 80 \\
\hline Mississippi & 43 & 0 & 25 & 10 \\
\hline Missouri & 0 & 16 & 23 & 144 \\
\hline Montana & 12 & 331 & 0 & 166 \\
\hline Nebraska & 3611 & 200 & 39 & 133 \\
\hline Nevada & 0 & 824 & 0 & 106 \\
\hline Now Hampshire & 25 & 0 & 0 & 0 \\
\hline New Jersey & 220 & 291 & 22 & 257 \\
\hline New Mexico & 7005 & 0 & 0 & 25 \\
\hline New York & 805 & 120 & 9 & 49 \\
\hline North Carolina & 28 & 29 & 0 & 0 \\
\hline North Dakota & 107 & 18 & 40 & 13 \\
\hline Ohio & 14 & 7 & 0 & 248 \\
\hline Oklahoma & 4 & 0 & 0 & 0 \\
\hline Oregon & 0 & 165 & 0 & 0 \\
\hline Pennsylvania & 30 & 60 & 0 & 93 \\
\hline Puerto Rico & 85 & 0 & 0 & 6 \\
\hline Rhode Island & 36 & 26 & 0 & 0 \\
\hline South Carolina & 56 & 0 & 1 & 0 \\
\hline South Dakota & 0 & 29 & 0 & 12 \\
\hline Tennessee & 20 & 15 & 15 & 14 \\
\hline Texas & 776 & 0 & 195 & 0 \\
\hline Utah & 1092 & 36 & 243 & 74 \\
\hline Vermont & 0 & 0 & 0 & 0 \\
\hline Virginia & 66 & 58 & 0 & 20 \\
\hline Washington & 20 & 158 & 0 & 493 \\
\hline West Virginia & 2 & 0 & 0 & 26 \\
\hline Wisconsin & 149 & 6 & 233 & 0 \\
\hline Wyoming & 67 & 170 & 0 & 217 \\
\hline Total & 22931 & 4393 & 2343 & 3191 \\
\hline
\end{tabular}


Table 6.-Num. of stations, by state, at which sediment and precipitation data were collected in FY 1997

Type of Station

\begin{tabular}{|c|c|c|c|c|}
\hline \multirow[t]{2}{*}{ State } & \multicolumn{2}{|c|}{ Sediment } & \multicolumn{2}{|c|}{ Precipitation } \\
\hline & $\begin{array}{r}\text { Daily } \\
\text { Sampling }\end{array}$ & $\begin{array}{r}\text { Periodic } \\
\text { Sampling }\end{array}$ & Quantity & Quality \\
\hline Alabama & 0 & 11 & 19 & 1 \\
\hline Alaska & 0 & 3 & 0 & 3 \\
\hline Arizona & 2 & 6 & 43 & 0 \\
\hline Arkansas & 4 & 12 & 67 & 1 \\
\hline California & 5 & 22 & 8 & 0 \\
\hline Colorado & 5 & 52 & 56 & 1 \\
\hline Connecticut & 0 & 0 & 2 & 0 \\
\hline Delaware & 0 & 0 & 0 & 0 \\
\hline Florida & 0 & 3 & 78 & 1 \\
\hline Georgia & 0 & 3 & 12 & 3 \\
\hline Hawail & 7 & 0 & 54 & 0 \\
\hline Idaho & 0 & 52 & 3 & 0 \\
\hline Illinois & 15 & 8 & 46 & 0 \\
\hline Indiana & 0 & 1 & 36 & 1 \\
\hline lowa & 15 & 2 & 6 & 2 \\
\hline Kansas & 0 & 13 & 4 & 2 \\
\hline Kentucky & 0 & 5 & 35 & 1 \\
\hline Louisiana & 0 & 14 & 46 & 0 \\
\hline Maine & 0 & 0 & 15 & 0 \\
\hline Maryland & 0 & 13 & 1 & 0 \\
\hline Massachusetts & 0 & 5 & 1 & 0 \\
\hline Michigan & 0 & 4 & 0 & 0 \\
\hline Minnesota & 2 & 3 & 8 & 1 \\
\hline Mississippi & 10 & 9 & 2 & 2 \\
\hline Missouri & 8 & 8 & 62 & 0 \\
\hline Montana & 5 & 22 & 26 & 2 \\
\hline Nebraska & 0 & 1 & 10 & 1 \\
\hline Nevada & 0 & 35 & 32 & 4 \\
\hline New Hampshire & 0 & 0 & 2 & 0 \\
\hline New Jersey & 0 & 78 & 2 & 2 \\
\hline New Mexico & 8 & 6 & 67 & 0 \\
\hline New York & 2 & 7 & 20 & 4 \\
\hline North Carolina & 0 & 17 & 59 & 0 \\
\hline North Dakota & 0 & 12 & 17 & 2 \\
\hline Ohio & 7 & 4 & 7 & 0 \\
\hline Oklahoma & 0 & 36 & 96 & 2 \\
\hline Oregon & 0 & 3 & 2 & 2 \\
\hline Pennsylvania & 0 & 21 & 90 & 0 \\
\hline Puerto Rico & 32 & 0 & 107 & 0 \\
\hline Rhode Island & 0 & 0 & 0 & 0 \\
\hline South Carolina & 0 & 1 & 24 & 1 \\
\hline South Dakota & 4 & 16 & 45 & 1 \\
\hline Tennessee & 0 & 20 & 45 & 1 \\
\hline Texas & 0 & 12 & 111 & 1 \\
\hline Utah & 0 & 4 & 0 & 1 \\
\hline Vermont & 0 & 0 & 0 & 0 \\
\hline Virginia & 4 & 5 & 27 & 0 \\
\hline Washington & 1 & 4 & 55 & 0 \\
\hline West Virginia & 2 & 0 & 1 & 1 \\
\hline Wisconsin & 3 & 9 & 24 & 6 \\
\hline Wyoming & 1 & 14 & 7 & 0 \\
\hline Total & 142 & 576 & 1480 & 50 \\
\hline
\end{tabular}


time discharge data to government agencies and the general public through the World-Wide Web. Near real time hydrologic data from more than half of the datacollection platforms that are operated by the USGS currently are available and can be accessed through the World-Wide Web; this facilitates near-instant dissemination and use of these data. In FY 1997, data-collection platforms were located in 4,467 U.S. Geological Survey hydrologic data-collection stations (table 1) and were transmitting data on one, or a combination, of the following variables: stream stage or discharge, reservoir stage, water quality, and precipitation. Of the 4,467 data-collection platforms in use in FY 1997, 3,965 stations were operated by the U.S. Geological Survey and 502 stations were operated by other cooperating agencies. The numbers of platforms in operation have increased steadily (table1) and are located nationwide (table7). 
Table 7.-Num. of stations, by state, at which data collection platforms were operated in FY 1997

Data Collection Platforms

\begin{tabular}{|c|c|c|}
\hline State & Operated by USGS & Operated by Other Agencies \\
\hline Alabama & 3 & 0 \\
\hline Alaska & 24 & 5 \\
\hline Arizona & 112 & 13 \\
\hline Arkansas & 90 & 3 \\
\hline California & 103 & 0 \\
\hline Colorado & 230 & 57 \\
\hline Connecticut & 15 & 14 \\
\hline Delaware & 0 & 0 \\
\hline Florida & 246 & 1 \\
\hline Georgia & 4 & 0 \\
\hline Hawaii & 0 & 0 \\
\hline Idaho & 45 & 58 \\
\hline Illinois & 31 & 34 \\
\hline Indiana & 74 & 21 \\
\hline lowa & 118 & 52 \\
\hline Kansas & 170 & 0 \\
\hline Kentucky & 96 & 0 \\
\hline Louisiana & 78 & 0 \\
\hline Maine & 56 & 0 \\
\hline Maryland & 17 & 3 \\
\hline Massachusetts & 15 & 18 \\
\hline Michigan & 0 & 0 \\
\hline Minnesota & 50 & 3 \\
\hline Mississippi & 75 & 9 \\
\hline Missouri & 130 & 0 \\
\hline Montana & 95 & 7 \\
\hline Nebraska & 50 & 0 \\
\hline Nevada & 37 & 2 \\
\hline New Hampshire & 27 & 0 \\
\hline New Jersey & 59 & 0 \\
\hline New Mexico & 80 & 6 \\
\hline New York & 65 & 14 \\
\hline North Carolina & 85 & 0 \\
\hline North Dakota & 39 & 0 \\
\hline Ohio & 30 & 78 \\
\hline Oklahoma & 149 & 0 \\
\hline Oregon & 38 & 25 \\
\hline Pennsylvania & 250 & 49 \\
\hline Puerto Rico & 111 & 0 \\
\hline Rhode Island & 0 & 0 \\
\hline South Carolina & 197 & 0 \\
\hline South Dakota & 36 & 0 \\
\hline Tennessee & 56 & 0 \\
\hline Texas & 366 & 0 \\
\hline Utah & 63 & 8 \\
\hline Vermont & 8 & 0 \\
\hline Virginia & 39 & 0 \\
\hline Washington & 173 & 0 \\
\hline West Virginia & 77 & 0 \\
\hline Wisconsin & 0 & 14 \\
\hline Wyoming & 53 & 8 \\
\hline Total & 3965 & 502 \\
\hline
\end{tabular}




\section{REFERENCES}

Burkham, D.C., 1985, An approach for appraising the accuracy of suspended-sediment data: U.S. Geological Survey Professional Paper 1333, 18 p.

Condes de la Torre, A., 1983, Operation of hydrologic data-collection stations by the U.S. Geological Survey in 1983: U.S. Geological Survey Open-File Report 83-862, 29 p.

1985, Operation of hydrologic data-collection stations by the U.S. Geological Survey in 1985: U.S. Geological Survey Open-File Report 85-640, 37 p.

1987, Operation of hydrologic data-collection stations by the U.S. Geological Survey in 1987: U.S. Geological Survey Open-File Report 87-563, 42 p.

1989 , Operation of hydrologic data-collection stations by the U.S. Geological Survey in 1989: U.S. Geological Survey Open-File Report 90-171, 52 p. 1991, Operation of Hydrologic data-collection stations by the U.S. Geological Survey in 1991: U.S. Geological Survey Open-File Report 92-172, 50 p. 1993, Operation of Hydrologic data-collection stations by the U.S. Geological Survey in 1993: U.S. Geological Survey Open-File Report 94-84, 53 p.

Lew, M., and Dodds, B.., 1996, Operation of hydrologic data-collection stations by the U.S. Geological Survey in 1995: U.S. Geological Survey Open-File Report 96-132, 28 p.

Gilbert, B.K., and Mann, W.B., IV, 1993, The U.S. Geological Survey Federal-State Cooperative Water-Resources Program, Fiscal Year 1992: U.S. Geological Survey OpenFile Report 93-120, $33 \mathrm{p}$.

Paulson, R.W., and Shope, W.G., Jr., 1984, Development of earth satellite technology for the telemetry of hydrologic data: Water Resources Bulletin,v. 20, no. 4, p. 611-618. 